\title{
ISLAMIC ENDOGENOUS MONEY: EVIDENCE FROM THE ISLAMIC BANKING SYSTEM IN INDONESIA AND MALAYSIA
}

\author{
Khoirul Umam ${ }^{1}$, Abdul Ghafar Ismail2 ${ }^{2}$ Achmad Tohirin ${ }^{3}$ and Jaka Sriyana ${ }^{4}$ \\ ${ }^{1}$ Universitas Darussalam Gontor, Indonesia, khoirulumam@unida.gontor.ac.id \\ ${ }^{2}$ Universiti Sains Islam Malaysia, Malaysia, agibab62@gmail.com \\ ${ }^{3}$ Universitas Islam Indonesia, Indonesia, achmad.tohirin@uii.ac.id \\ ${ }^{4}$ Universitas Islam Indonesia, Indonesia, jakasriyana@uii.ac.id
}

\begin{abstract}
This paper proposes a theoretical model of endogenous Islamic money and empirically analyses the endogeneity of Islamic money supply under fiat and fractional reserve systems. The causal relations between Islamic money and macro and financial variables are assessed using the autoregressive distributed lag (ARDL) model and error-correction modelling (ECM). The results suggest that the greater the maturity and the larger the asset share in the Islamic financial system, the better the endogeneity of money. They also reveal that the profit and loss sharing system can connect the economy to money, minimise the exogenous potential of the fractional reserve requirement system, and eliminate the exogenous feature of the fiat money system. Accordingly, the study argues that an Islamic endogenous money system can be developed in fiat and fractional reserve banking systems.
\end{abstract}

Keywords: Endogenous Islamic money, Islamic M2, Indonesian Islamic banks, Malaysian Islamic banks.

JEL classification: G18; G21; G28.

Article history:

Received : October 15, 2020

Revised : February 17, 2021

Accepted : : May 27, 2021

Available online : August 31, 2021

https://doi.org/10.21098/jimf.v7i3.1351 


\section{INTRODUCTION}

\subsection{Background}

Historically, the debate on whether money is the cause of inflation can be traced to two contradictory views; i.e., the "endogenous money" view versus "exogenous money" view. The first view posits that money is not the cause of inflation, while the second argues the opposite. Regarding the view that money is endogenous, Moore (1988) proposes that central banks adopt an accommodative policy in relation to the creation of money. On the contrary, based on the second view, Friedman (2010) contends that they should target money supply growth. Interestingly, this debate began after John Law's fiat money experiment (1716-1720), the root of the real bills doctrine theory, which opposed the mainstream quantity theory of money, which posits that the over-issuance of money supply will create inflation. It then continued the debate in 1797-1821, in what was known as the Bullionist Controversy (Laidler, 1989), later in the 1940s as the Currency-Banking Debate (Skaggs, 1999), and currently as the debate between post-Keynesianism and monetarism.

In these two contradictory perspectives of money and inflation, contemporary Muslim economists follow the mainstream theory of money, treating it exogenously. This exogenous-based Islamic monetary theory has become the basis of empirical studies on the Islamic monetary system. For example, Darrat (1988) demonstrates that money in the Islamic financial system is more stable and more useful for monetary policy than in the conventional system. Darrat's framework has subsequently been followed by the work of Yousefi, Abizadeh, and McCormick (1997), Darrat (2000), Kia (1998), and Kia and Darrat (2003) in the context of Iran; Hassan and Aldayel (1998) in relation to 15 Muslim countries (Bahrain, Kuwait, Saudi Arabia, UAE, Indonesia, Malaysia, Pakistan, Algeria, Egypt, Morocco, Tunisia, Iran, Jordan, Syria, and Turkey); Kaleem (2000) with regard to Malaysia; and Izhar and Asutay (2007), Ascarya (2012) and Fikri (2018) in the context of Indonesia.

Assuming the exogeneity of money, these empirical studies only capture the efficiency of monetary policy, but not the true money supply in an economy. In Choudhury's (1997) analysis, exogenous money comes from the non-real economy demand for money and the exogenous supply of it. With these features, money supply will not reflect the needs of the real economy and will create an un-true value of money in the real economy. Choudhury (1997) contends that endogenous money should be the framework of Islamic monetary theories, as such money will not cause inflation and harm the economy.

It should be noted that Choudhury's (1997) endogenous money is different to the conventional notion of it, which refers empirically to the causality running from the economy to money supply and monetary authorities. In addition, Choudhury's (1997) endogeneity concept refers to money being free from its price. Therefore, based on these differing concepts of endogenous money, the conventional type does not see any problem with interest systems, while with endogenous Islamic money it is believed that interest causes money to have its price. In addition, Choudhury (1997) excludes fiat and fractional reserve banking systems from the endogenous money system. 
In light of these arguments, this paper raises the following research questions:

Is the Islamic endogenous money concept applicable in the current fiat and fractional reserve systems?

What are the essential features of endogenous money in the view of classical ulama and contemporary Muslim economists?

What empirical evidence could be revealed from the current practices of Islamic banking and the capital market system?

\subsection{Objective}

In light of the above questions, the paper aims to re-analyse Choudhury's (1997) endogenous money and propose a theoretical and empirical Islamic endogenous money model. It employs ARDL modelling to empirically evaluate the endogeneity of money using Malaysia and Indonesia as case studies. Malaysia is a leading country in Islamic finance (Islamic Finance Development Indicator, 2019) and since the 1997/1998 financial crisis its Islamic financial sector has shown remarkable progress. In particular, its Islamic banking segment has witnessed a substantial increase in its financing share, from $5 \%$ before the crisis, to more than 25\% in 2019 (Ibrahim, 2020). In addition, Indonesia is the country with the largest Muslim population. While its Islamic banking share is still only 5.99\% (OJK, 2020), it has a larger proportion of profit-sharing based finance compared to Malaysia. Therefore, Indonesia is closer to the spirit of Islamic finance as, according to Chapra (2008), the profit-loss-sharing arrangement is a key feature of the Islamic banking system. By considering these two countries, the paper aims to develop a comprehensive picture of endogenous money in Islamic banking.

The paper comprises five sections. Section 1 is the introduction, which elaborates the background of the research problems and objectives. The literature review, which presents the theoretical basis of Islamic endogenous money and the position of this study among previous research, is presented in section 2. Section 3 explains the research methodology, including an explanation of the data, the model development and the empirical method used. The results and analysis are discussed in section 4 , while the final section comprises the conclusion and recommendations.

\section{LITERATURE REVIEW}

\subsection{Islamic Endogenous Money}

Choudhury's (1997) essential feature of endogenous money is the absence of the price of money. This price will distort money's ability to become an accurate measure of real economic activities. Because of this inability to reflect its actual value, money consequently cannot fairly mediate exchange. In other words, the exogenous money system leads to ab un-true value of money, while the endogenous one reflects the real value of economic activities.

According to Choudhury (1997), the sources of the price of money are from

the demand and supply sides. In his criticism of conventional money theory, Choudhury writes, "Such theories are based on the philosophy of money being exogenous stock. Therefore, it must carry with it a price of its own. Such a price is based on the 
expectation nature of money demand (speculation) on the one hand, and the price of the stock set by monetary authorities (supply), on the other" (Choudhury, 1997, p. 51). Specifically, Choudhry's first source is Keynes' (1936) speculative motive of money demand, while the second source is monetary policy based on interest rates to manage the supply of money.

This conceptual logic of endogenous money has its root in Imam Ghazali's (2013 M/1434 H) concept of money. He writes that any activity employing money outside its functions is injustice "iż talabu an-naqdi liǵayri ma wudi 'a lahù żulm" (AlGhazali, 2013 M/1434 H, p.123). One example given by Imam Ghazali is riba, which results in money being traded and having a price. In other words, he believes that any demand for money that emerges from any motive that is not related to exchange is an exogenous factor that will harm the economy.

Accordingly, in the current fiat and fractional reserve requirement systems, the exogenous speculative demand for money comes from speculation in the financial market. Such speculative activities exist because of fluctuations in financial market prices, meaning that the speculators can proceed with their actions. Toutounchian (2009) argues that the fluctuation in prices still exists in the Islamic financial market. In this regard, the exogenous factor of money supply can come from this market. Therefore, Islamic money endogenicity can be analysed in terms of the absence of causality from the Islamic financial market to money supplied in the economy.

In addition to the demand for money, since the speculative motive is the source of exogenous money, the transactional motive becomes the demand for endogenous money. Based on this rationale, Islamic money endogenicity exists if the real economy has a causality relationship with the money supplied in the economy. Moore (1988) considers this idea to be one of main features of postKeynesian endogenous money. Furthermore, Chapra (1996) clearly asserts that the transactional motive includes un-Islamic luxury and wasteful motives. Such motives cannot be expressed in the current macroeconomic variables, such as gross domestic product and the industrial production index. However, the price of property can be an attractive alternative to luxury and wasteful motives. Accordingly, Islamic endogenicity can be demonstrated by the absence of causality between property prices and money supply.

The second source of exogenous money is its supply. In a fiat monetary system, monetary authorities have exogenous power to supply money to the economy. This power comes from their ability to target money supply and interest rates using three monetary policy tools: open market operations, changes in discount lending, and changes in reserve requirements (Mishkin, 2004, p. 393). These tools are adopted into Islamic monetary policy by changing the interest system to the Sharia one. In this regard, Islamic endogenicity can be analysed by the causality from money supply to the monetary base and Islamic monetary instrument, but not vice versa.

In addition to the exogenous power of authority, Meera (2002) argues that exogenous money might not increase price levels because the government intervenes in these. This price intervention leads to the interesting notion that the government can intervene in money supply through such a process. Therefore, in this regard, Islamic endogenicity can be seen in terms of the absence of causality from price levels to money supply. 
From the above discussion, some related features can be derived for the model of endogenous Islamic money. These are classified into three groups: the relationships between money and the economy, between money and prices, and between money and monetary policies.

\section{Three groups of endogenous Islamic features}

1st Group of Money and Economy

- Islamic money endogenicity is demanded by the transactional motive: causality from real economic activities to money supply

- $\quad$ 2nd Group of Money and Prices

- The exogenous factor can come from price level intervention

- Islamic money endogenicity is not demanded by the speculative motive: no causality from financial asset prices to money supply

- Luxury and wasteful transactional motive of property prices: no causality from property prices to money supply

- $\quad 3 r d$ Group of Money and Monetary Policies

- Islamic money endogenicity is not supplied exogenously by monetary authorities: causality from money supply to monetary base, but not vice versa

- Causality from money to the monetary instrument, but not vice versa

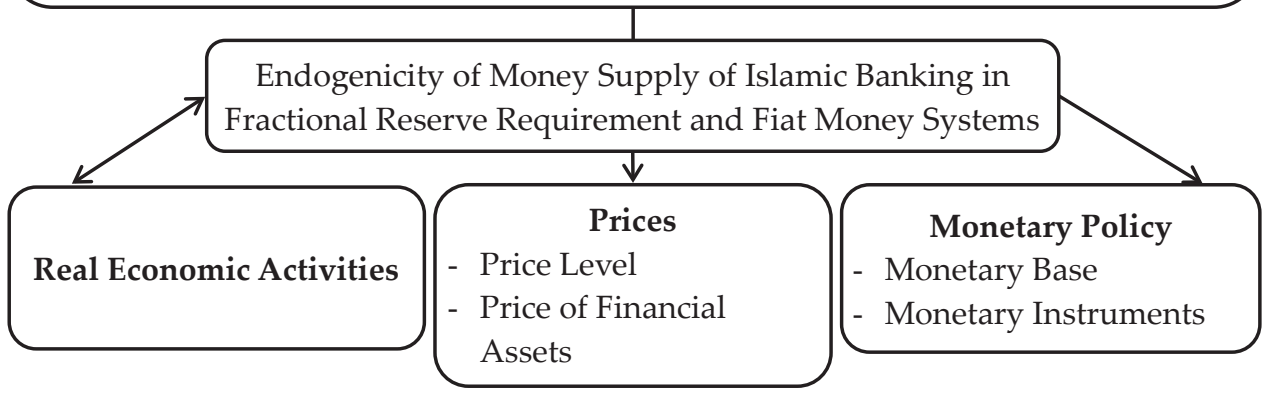

Figure 1.

Islamic Endogenous Money Theoretical Framework

From these three groups of endogenous Islamic features, the first explains the relationship between money and real economic activities. If a causality relationship exists from real economic activities to money supply, the first feature of Islamic money endogenicity is achieved. The second group analyses the relationship between money and prices. If there is no causality relationship from prices to money, Islamic moey endogenicity exists. Finally, the third group explains Islamic endogenicity in terms of the relationship between money supply and monetary policy. In this regard, Islamic money endogenicity is achieved when the exogenous power of monetary authorities in creating money does not determine the money supply, but on the contrary, money determines its creation by the monetary authorities. In other words, Islamic endogeneity is achieved if there is a causality relationship from money to monetary policy, but not vice versa. 


\subsection{Previous Studies}

Empirical studies on endogenous money have been made by many researchers, such as Cyrille and Christophe (2020) for the CEMAC (Central African Economic and Monetary Community) area; Haghighat (2011) for Iran; Lavoie (2005) for Canada and America; Shanmugam, Nair, and Li (2003) for Malaysia; Vera (2001) for Spain; Nell (2000) for South Africa; and Pollin (1991) for the USA. These studies show empirically that money is endogenous. However, they are based on the conventional endogenous money concept and not the Islamic one. In this regard, no previous studies have empirically investigated the Islamic endogenous money concept.

The existing empirical research on money in Islam, namely the money supplied in the Islamic financial system, is based on the exogenous money assumption. There are numerous empirical studies (Darrat, 1988, 2000; Yousefi, Abizadeh, \& McCormick, 1997; Kia, 1998; Kia \& Darrat, 2003; Hassan \& Aldayel, 1998; Kaleem, 2000; Izhar \& Asutay, 2007; Ascarya, 2012; Fikri, 2018) that have investigated the effectiveness of money supply in the Islamic banking system. These studies are primarily based on exogenous money, while there have been no empirical studies on whether or not money in Islam is endogenous

Interestingly, Choudhury (1997) contends that money in Islam is endogenous, but that this feature is not taken as the base for the Islamic money concept, and even not mentioned by contemporary Muslim economists. Toutouchian (2009) refers to the feature, but not as the basis for analysis. The majority of studies, such as those of Chapra (1996) and Meera (2002), do not explicitly consider this feature, preferring to follow the mainstream exogenous money-based concept. This indicates that endogenous money has not reached a consensus and remains a puzzle in the Islamic money literature. However, we believe that Choudhury's (1997) endogenous money concept has its roots in the Islamic money concept of Imam Ghazali (2013 M/1434 H) in his Ihya' Ulumuddin and also in Chapra's (1996) and Meera's (2002) concepts of Islamic money demand and dinar money, respectively. Therefore, this paper aims to solve this puzzle by developing a model of Islamic endogenous money based on Choudhury (1997), Imam Ghazali (2013 M/1434 H), Chapra (1996), and Meera (2002).

In addition, Choudhury's endogenous money considers that the fiat and fractional reserve banking systems are exogenous. Therefore, this leads to another gap that indicates that Islamic endogenous money is not applicable in the fiat and fractional reserve banking systems. With the rapid development of the Islamic banking system based on fiat and fractional reserve systems, this paper tests the proposed endogenous model in the current Islamic fiat and fractional reserve banking systems. By doing so, the aim is to solve the puzzle of whether Islamic endogenous money is applicable in the fiat and fractional reserve systems.

\section{DATA AND METHODOLOGY}

\subsection{Data}

The data were compiled for the following variables in both the Malaysian and Indonesian contexts: Islamic money (IM2), monetary base $\left(\mathrm{M}_{0}\right)$, Islamic monetary instrument (IMI), Industrial production index (IPI), consumer price index (CPI), property prices (Pr), and stock prices (SP). Apart from property and stock prices, the 
data for Indonesia were taken from Indonesian Economic and Financial Statistics (SEKI), Bank Indonesia and Sharia Banking Statistics (SPS), the Indonesia Financial Services Authority, and Statistics Indonesia ; and for Malaysia from Bank Negara Malaysia Statistics. Property prices and stock prices were taken respectively from CEIC (Census and Economic Information Center) Data's Global Database and Bloomberg for both countries. All the data were monthly from January 2013 to December 2019, except for Malaysia's IPI and SP, which were from January 2015 - December 2015.

We constructed IM2 for the Islamic financial system by aggregating the currency in circulation, Islamic demand deposits, and investment plus fixed deposit money held in the Islamic banking scheme. The Islamic monetary instrument for Indonesia was represented by the Bank Indonesia Sharia Certificate (SBIS), while for Malaysia by the Islamic Interbank Money Market rate. As for stock prices, we used the Indonesia Sharia Stock Index (ISSI) and FTSE Bursa Malaysia EMAS Sharia (FBMS).

\subsection{Model Development}

Figure 2 shows the theoretical relations between endogenous Islamic money (IM2) and three sets of variables representing (i) the real economy, (ii) prices and (iii) monetary policy, which were based on Choudhury's (1997) Islamic endogenous money concept, and elaborated further by the money concepts of proposed by Imam Ghazali (2013 M/1434 H), Chapra (1996) and Meera (2002).

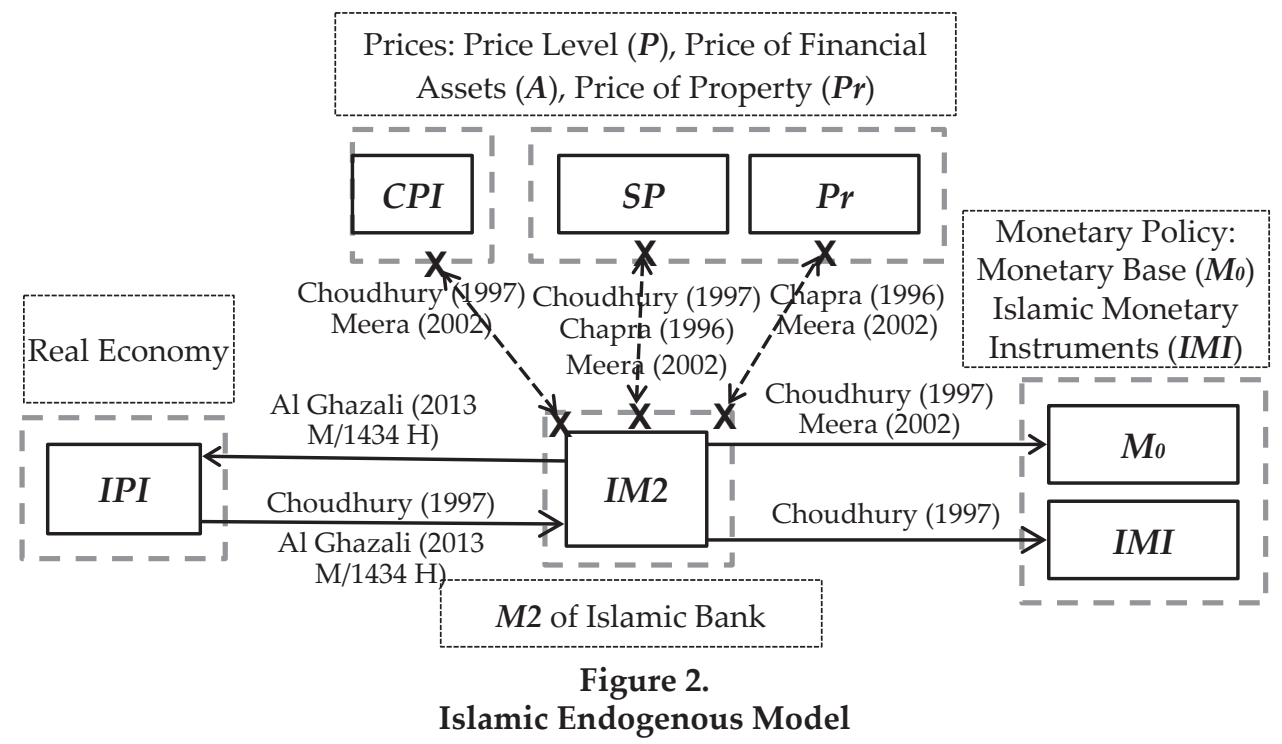

As can be seen in Figure 2, there are three sets of relations between IM2 and the financial and economic variables. The first set of relations relates to the those between IM2 and the real economy. The endogenous Islamic money theory essentially posits the causal relation that runs from real output, represented by the 
industrial production index (IPI), to Islamic money (IM2), although the presence of reverse causality from Islamic money to real activity would not negate the endogeneity of money. The second set of relations involves IM2 and prices. It is postulated that endogenicity exists if these are causally independent; that is, there is no causal relation between prices (CPI, SP, and Pr) and IM2. Finally, the third set of models link IM2 to monetary policy, in which the latter is represented by the monetary base $\left(\mathrm{M}_{0}\right)$ and the Islamic monetary instrument (IMI). Islamic endogenicity hypothesises (i) causality from IM2 to $\mathrm{M}_{0}$ and fromIM2 to IMI and (ii) the absence of causality from $\mathrm{M}_{0}$ to IM2 and from IMI to IM2.

\subsection{Method}

Based on Figure 2, the assessment of Islamic money endogeneity requires the establishment of the causal relations between IM2 and the variables representing the real economy (IPI), prices (CPI, SP and Pr) and monetary policy $\left(\mathrm{M}_{0}, \mathrm{IMI}\right)$. To this end, we performed pairwise Granger causality tests between IM2 and the other variables considered in the analysis. Representing IM2 by y and another variable under focus by $\mathrm{x}$, we performed the tests using the following equations:

$$
\begin{aligned}
& \Delta y_{t}=\alpha_{0}+\sum_{i=1}^{p} \alpha_{1 i} \Delta y_{t-i}+\sum_{i=1}^{p} \alpha_{2 i} \Delta x_{t-i}+\gamma_{1} E C T_{t-1}+\varepsilon_{1 t} \\
& \Delta x_{t}=\theta_{0}+\sum_{i=1}^{p} \theta_{1 i} \Delta y_{t-i}+\sum_{i=1}^{p} \theta_{2 i} \Delta x_{t-i}+\gamma_{2} E C T_{t-1}+\varepsilon_{2 t}
\end{aligned}
$$

where ECT represents the deviation from the long-run relation between $\mathrm{y}$ and x; i.e., $E C T_{t-1}=y_{t}-\beta_{0}-\beta_{1} x_{t}$.

Equations (1) and (2) are essentially a bivariate vector error-correction model, which specifies two sources of causality between the variables. Based on (1), these two sources are short-run and long-run causality, captured respectively by $\sum_{i=1}^{p} \alpha_{2 i}$ and $\gamma_{1}$. The significance of $\sum_{i=1}^{p} \alpha_{2 i}$ means that there exists short-run causality from $\mathrm{x}$ to $\mathrm{y}$. On the other hand, the significance of $\gamma_{1}$ indicates long-run causality from $x$ to $y$. It should be noted that if there is no long run relation between the variables under investigation, then ECT should be omitted from the models. The causality between the variables can be ascertained by examining the significance of the coefficient sum of the lagged first-differenced variables in the equation. The causal assessment from equation (2) can be made in the same manner. From the tests of significance, four patterns of causality between $y$ and $x$ could be established: (i) there are feedback effects between $y$ and $x$; i.e., they are causally linked in both directions; (ii) there is a causal relation only from $\mathrm{x}$ to $\mathrm{y}$; (iii) there is a causal relation only from $y$ to $x$; and (iv) they are causally independent. Based on these patterns, we can infer the endogeneity of IM2.

In arriving at the final specification of (1) and (2), i.e. whether ECT should be included or not, we proceeded accordingly to the standard steps in timeseries econometrics. In the first step, we conducted ADF and PP unit root tests to establish the integration properties of the variables. We then performed the ARDL cointegration test to establish the presence of their long-run relation. The ARDL test was adopted in this study due to the small sample size, together with its ability 
to incorporate both $\mathrm{I}(0)$ and $\mathrm{I}(1)$ variables in the model, unlike the normally used Engle-Granger or Johansen-Juselius cointegration tests. Finally, if there existed a long-run relation between the variables, we employed (1) and (2) above to conduct the Granger causality tests. In contrast, if no long-run relations existed, ECT was omitted and the Granger causality tests were based only on short-run causality.

\section{RESULTS AND ANALYSIS}

\subsection{Data Preliminaries}

In Table 1, the ADF and PP unit root tests show that all the Indonesian and Malaysian Islamic variables are stationary at level and first difference. The lag chosen for ADF was based on AIC, while for PP it was based on Newey \& West's (1987) bandwidth. For the Indonesian data, both ADF and PP tests confirmed that IM2, IPI, and SP are stationary at first difference, while CPI and Pr are stationary at level. The difference result of the tests takes place in $\mathrm{M}_{0}$, which is stationary at level according to ADF, and stationary at first difference according to PP. Another contradictory result can be seen in IMI, which is stationary at level according to ADF and stationary at first difference according to PP.

In the case of Malaysia, Table 1 shows that IM2, CPI, $\mathrm{M}_{0}$, and IMI are stationary at first difference, while SP and Pr are stationary at level according to both tests. IPI is stationary at first difference according to ADF and stationary at level according to PP.

Table 1.

\section{Unit Root Tests}

(a) Indonesia

\begin{tabular}{lcccc}
\hline \multirow{2}{*}{ Variable } & \multicolumn{2}{c}{ Level } & \multicolumn{2}{c}{ First Difference } \\
\cline { 2 - 5 } & ADF & PP & ADF & PP \\
\hline IM2 & 0.197 & -0.491 & $-3.805^{*}$ & $-39.784^{*}$ \\
IPI & -0.672 & -1.494 & $-6.204^{*}$ & $-87.698^{*}$ \\
CPI & $-2.732^{* * *}$ & $-3.127^{* *}$ & -2.121 & $-6.394^{*}$ \\
SP & -1.793 & -1.994 & $-7.926^{*}$ & $-7.913^{*}$ \\
Pr & $-5.917^{*}$ & $-6.928^{*}$ & $-11.755^{*}$ & $-11.362^{*}$ \\
M0 & $-3.757^{*}$ & -1.815 & -2.306 & $-19.969^{*}$ \\
IMI & $-2.698^{* * *}$ & -2.187 & $-3.940^{*}$ & $-7.388^{*}$ \\
\hline
\end{tabular}

(b) Malaysia

\begin{tabular}{lcccc}
\hline \multirow{2}{*}{ Variable } & \multicolumn{2}{c}{ Level } & \multicolumn{2}{c}{ First Difference } \\
\cline { 2 - 5 } & ADF & PP & ADF & PP \\
\hline IM2 & -0.341 & -0.229 & $-7.751^{*}$ & $-7.735^{*}$ \\
IPI & -0.809 & $-3.075^{* *}$ & $-10.745^{*}$ & $-21.913^{*}$ \\
CPI & -1.647 & -1.442 & $-5.179^{*}$ & $-7.299^{*}$ \\
SP & $-3.061^{* *}$ & $-3.113^{* *}$ & $-8.807^{*}$ & $-8.892^{*}$ \\
Pr & $-4.338^{*}$ & $-3.287^{* *}$ & $-5.899^{*}$ & $-4.251^{*}$ \\
M0 & -1.947 & -1.039 & $-2.798^{* * *}$ & $-14.713^{*}$ \\
IMI & -1.825 & -1.894 & $-7.849^{*}$ & $-7.849^{*}$ \\
\hline
\end{tabular}

Note: *significant at $1 \%$; ${ }^{* *}$ significant at $5 \%$; ${ }^{* * *}$ significant at $10 \%$ 
Tables 2 and 3 summarise the cointegration results. Cointegration takes place in ten models; five Indonesian and five Malaysian. Indonesia and Malaysia have the same four cointegrated models, namely IM2=f(IPI), IPI=f(IM2), SP=f(IM2), and $\operatorname{Pr}=f(I M 2)$. The differences between them are $I M I=f(I M 2)$ and $M_{0}=f(I M 2)$ for the Indonesian and Malaysian ones respectively. In other words, the different long run relationships between the Indonesian and Malaysian models refer to the relationship between IM2 and Monetary policy, and IM2 and the monetary base, respectively.

Table 2.

ARDL Cointegration Tests- Indonesia

\begin{tabular}{|c|c|c|c|}
\hline Systems & Lags & F-Stat & Conclusion \\
\hline \multicolumn{4}{|l|}{ (a) IM2, IP } \\
\hline IPI $\rightarrow$ IM2 & ARDL(1,3) & $15.06^{*}$ & Cointegrated \\
\hline IM2 $\rightarrow$ IPI & ARDL $(1,4)$ & $31.635^{*}$ & Cointegrated \\
\hline \multicolumn{4}{|l|}{ (b) IM2, CPI } \\
\hline $\mathrm{CPI} \rightarrow \mathrm{IM} 2$ & ARDL(2,3) & 4.211 & Not Cointegrated \\
\hline $\mathrm{IM} 2 \rightarrow \mathrm{CPI}$ & $\operatorname{ARDL}(3,2)$ & 2.911 & Not Cointegrated \\
\hline \multicolumn{4}{|l|}{ (c) IM2, SP } \\
\hline $\mathrm{SP} \rightarrow \mathrm{IM} 2$ & ARDL $(4,2)$ & 1.147 & Not Cointegrated \\
\hline $\mathrm{IM} 2 \rightarrow \mathrm{SP}$ & $\operatorname{ARDL}(3,0)$ & $6.401^{* *}$ & Cointegrated \\
\hline \multicolumn{4}{|l|}{ (d) IM2, Pr } \\
\hline $\mathrm{Pr} \rightarrow \mathrm{IM} 2$ & $\operatorname{ARDL}(2,0)$ & 3.877 & Not Cointegrated \\
\hline IM2 $\rightarrow$ Pr & $\operatorname{ARDL}(4,0)$ & $10.228^{*}$ & Cointegrated \\
\hline \multicolumn{4}{|l|}{ (e) IM2, $\mathrm{M}_{0}$} \\
\hline $\mathrm{M}_{0} \rightarrow \mathrm{IM} 2$ & ARDL(1,1) & 1.975 & Not Cointegrated \\
\hline $\mathrm{IM} 2 \rightarrow \mathrm{M}_{0}$ & $\operatorname{ARDL}(2,1)$ & 3.187 & Not Cointegrated \\
\hline \multicolumn{4}{|l|}{ (f) IM2, IMI } \\
\hline IMI $\rightarrow$ IM2 & $\operatorname{ARDL}(4,0)$ & 1.304 & Not Cointegrated \\
\hline IM2 $\rightarrow$ IMI & $\operatorname{ARDL}(3,0)$ & $6.984^{* *}$ & Cointegrated \\
\hline
\end{tabular}

Table 3.

ARDL Cointegration Tests - Malaysia

\begin{tabular}{llll}
\hline \multicolumn{1}{c}{ Systems } & \multicolumn{1}{c}{ Lags } & \multicolumn{1}{c}{ F-Stat } & \multicolumn{1}{c}{ Conclusion } \\
\hline (a) IM2, IP & & & \\
\hline IPI $\rightarrow$ IM2 & ARDL(1,4) & $4.912^{* * *}$ & Cointegrated \\
IM2 $\rightarrow$ IPI & ARDL(4,3) & $5.467^{* * *}$ & Cointegrated \\
\hline (b) IM2, CPI & & \\
\hline CPI $\rightarrow$ IM2 & ARDL(2,1) & 0.839 & Not Cointegrated \\
IM2 $\rightarrow$ CPI & ARDL(3,4) & 1.349 & Not Cointegrated \\
\hline (c) IM2, SP & & & Not Cointegrated \\
\hline SP $\rightarrow$ IM2 & ARDL(1,0) & 2.939 & Cointegrated \\
\hline IM2 $\rightarrow$ SP & ARDL(1,1) & $7.808^{* *}$ & \\
\hline
\end{tabular}


Table 3.

ARDL Cointegration Tests - Malaysia (Continued)

\begin{tabular}{llll}
\hline \multicolumn{1}{c}{ Systems } & \multicolumn{1}{c}{ Lags } & \multicolumn{1}{c}{ F-Stat } & \multicolumn{1}{c}{ Conclusion } \\
\hline (d) IM2, Pr & & & \\
\hline Pr $\rightarrow$ IM2 & ARDL(2,0) & 0.348 & Not Cointegrated \\
IM2 $\rightarrow$ Pr & ARDL(4,0) & $5.102^{* * *}$ & Cointegrated \\
\hline$\left(\right.$ e) IM2, $\mathrm{M}_{0}$ & & & \\
\hline $\mathrm{M}_{0} \rightarrow$ IM2 & ARDL(1,1) & 0.279 & Not Cointegrated \\
$\mathrm{IM} 2 \rightarrow \mathrm{M}_{0}$ & ARDL(1,0) & $9.684^{*}$ & Cointegrated \\
\hline (f) IM2, IMI & & & Not Cointegrated \\
IMI $\rightarrow$ IM2 & ARDL(1,0) & 0.242 & Not Cointegrated \\
IM2 $\rightarrow$ IMI & ARDL(1,0) & 1.737 & \\
\hline
\end{tabular}

\subsection{Causality Tests}

On the basis of the above results, we conducted long- and short-run causality tests on the cointegrated models and a short-run test for the non-cointegrated models. The results summarised in Tables 4 and 5 indicate that bidirectional short- and long-run causalities occurred to IM2 and IPI and unidirectional short- and longrun ones from IM2 to SP for both the Indonesian and Malaysian models, while long-run causality existed from IM2 to Pr for both countries. Other short- and longrun causalities took place from IM2 to IMI and from IM2 to $\mathrm{M}_{0}$ for the Indonesian and Malaysian models respectively.

For the non-cointegrated models, we found a marked contrast between the Indonesian and Malaysian short-run causality results. Most of the Indonesian models had short-run causality apart from IMI to IM2, while in Malaysian ones, none of the non-cointegrated models had short run causalities, except for SP to IM2.

Table 4.

Causality Tests - Indonesia

\begin{tabular}{lccc}
\hline \multicolumn{3}{c}{ Sources of Causality } \\
\hline Systems & $\begin{array}{c}\text { Short Run } \\
\text { Wald } F \text {-Test }\end{array}$ & $\begin{array}{c}\text { Long Run } \\
\text { ECTt-1 [t-Stat] }\end{array}$ & Conclusion \\
\hline (a) IM2, IPI & & & \\
\hline IPI $\rightarrow$ IM2 & $8.537^{*}$ & $-0.535[-5.525]^{*}$ & $\begin{array}{c}\text { Long- and Short-Run } \\
\text { Causalities } \\
\text { Long- and Short-Run } \\
\text { Causalities }\end{array}$ \\
\hline IM2 $\rightarrow$ IPI & $12.093^{*}$ & $-0.974[-8.008]^{*}$ & \\
\hline (b) IM2, CPI & & & $\begin{array}{c}\text { Short-Run Causality } \\
\text { SPI } \rightarrow \text { IM2 }\end{array}$ \\
IM2 $\rightarrow$ CPI & $11.153^{*}$ & & Short-Run Causality \\
\hline (c) IM2, SP & $6.725^{*}$ & & Long- and Short-Run \\
\hline SP $\rightarrow$ IM2 & $3.839^{* *}$ & & Causalities \\
IM2 $\rightarrow$ SP & $9.169^{*}$ & $-0.199[-3.602]^{*}$ & \\
\hline
\end{tabular}


Table 4.

Causality Tests - Indonesia (Continued)

\begin{tabular}{lccc}
\hline \multicolumn{4}{c}{ Sources of Causality } \\
\hline Systems & $\begin{array}{c}\text { Short Run } \\
\text { Wald F-Test }\end{array}$ & $\begin{array}{c}\text { Long Run } \\
\text { ECTt-1 [t-Stat] }\end{array}$ & Conclusion \\
\hline (d) IM2, Pr & & & \\
\hline Pr $\rightarrow$ IM2 & $6.775^{* *}$ & & Short-Run Causality \\
$\mathrm{IM} 2 \rightarrow \operatorname{Pr}$ & 0.116 & $-0.013[-4.553]^{*}$ & Long-Run Causality \\
\hline$(\mathrm{e}) \mathrm{IM} 2, \mathrm{M}_{0}$ & & & \\
\hline $\mathrm{M}_{0} \rightarrow \mathrm{IM} 2$ & $199.111^{*}$ & & Short-Run Causality \\
$\mathrm{IM} 2 \rightarrow \mathrm{M}_{0}$ & $179.005^{*}$ & & Short-Run Causality \\
\hline$(\mathrm{f}) \mathrm{IM} 2, \mathrm{IMI}$ & & & \\
\hline $\mathrm{IMI} \rightarrow \mathrm{IM} 2$ & 1.799 & & Long- and Short-Run \\
$\mathrm{IM} 2 \rightarrow$ IMI & $6.205^{* *}$ & $-0.117[-3762]^{*}$ & Causalities \\
\hline
\end{tabular}

Table 5.

Causality Tests - Malaysia

\begin{tabular}{|c|c|c|c|}
\hline \multicolumn{4}{|c|}{ Sources of Causality } \\
\hline Systems & $\begin{array}{l}\text { Short Run } \\
\text { Wald F-Test }\end{array}$ & $\begin{array}{c}\text { Long Run } \\
\text { ECTt-1 (t-Stat) }\end{array}$ & Conclusion \\
\hline \multicolumn{4}{|l|}{ (a) IM2, IPI } \\
\hline IPI $\rightarrow$ IM2 & $2.805^{* *}$ & $-0.071[-3.166]^{*}$ & $\begin{array}{l}\text { Long- and Short-Run } \\
\text { Causalities }\end{array}$ \\
\hline IM2 $\rightarrow$ IPI & $16.163^{*}$ & $-0.646[-3.342]^{*}$ & $\begin{array}{l}\text { Long- and Short-Run } \\
\text { Causalities }\end{array}$ \\
\hline \multicolumn{4}{|l|}{ (b) IM2, CPI } \\
\hline $\mathrm{CPI} \rightarrow \mathrm{IM} 2$ & 2.074 & & No Causalities \\
\hline $\mathrm{IM} 2 \rightarrow \mathrm{CPI}$ & 1.774 & & No Causalities \\
\hline \multicolumn{4}{|l|}{ (c) IM2, SP } \\
\hline $\mathrm{SP} \rightarrow \mathrm{IM} 2$ & $5.849^{* *}$ & & Short-Run Causality \\
\hline $\mathrm{IM} 2 \rightarrow \mathrm{SP}$ & $3.051^{* * *}$ & $-0.208[-3.977]^{*}$ & $\begin{array}{l}\text { Long- and Short-Run } \\
\text { Causalities }\end{array}$ \\
\hline \multicolumn{4}{|l|}{ (d) IM2, Pr } \\
\hline $\operatorname{Pr} \rightarrow$ IM2 & 0.581 & & No Causalities \\
\hline $\mathrm{IM} 2 \rightarrow \operatorname{Pr}$ & 0.104 & $-0.021[-3.216]^{*}$ & $\begin{array}{l}\text { Long- and Short-Run } \\
\text { Causalities }\end{array}$ \\
\hline \multicolumn{4}{|l|}{ (e) IM2, $M_{0}$} \\
\hline $\mathrm{M}_{0} \rightarrow \mathrm{IM} 2$ & 2.221 & & No Causalities \\
\hline $\mathrm{IM} 2 \rightarrow \mathrm{M}_{0}$ & $17.489^{*}$ & $-0.365[-4.428]^{*}$ & $\begin{array}{l}\text { Long- and Short-Run } \\
\text { Causalities }\end{array}$ \\
\hline \multicolumn{4}{|l|}{ (f) IM2, IMI } \\
\hline IMI $\rightarrow$ IM2 & 0.001 & & No Causalities \\
\hline $\mathrm{IM} 2 \rightarrow \mathrm{IMI}$ & 0192 & & No Causalities \\
\hline
\end{tabular}




\subsection{Analysis}

An analysis of the endogeneity of money was conducted based on the three sets of relations between IM2 and the real economy, IM2 and prices, and IM2 and monetary policy. The test results for first set of relations reveal short- and long-run causalities from the economy (IPI) to IM2 in both the Indonesian and Malaysian banking cases. This empirical evidence indicates the existence of the endogeneity of money in the Islamic banking system in both countries. Specifically, money is supplied by the demand from real economic activities. This is in line with the basic idea of conventional endogenous money proposed by Moore (1986) and (1988), the main figure amongst post-Keynesian economists. Several centuries ago, Imam Ghazali $(2013 \mathrm{M} / 1434 \mathrm{H})$ stated that money was simply a mirror of economic activities. In other words, the causality from the economy to IM2 denotes that money is a reflection of economic activities and not a reflection of itself.

With regard to the reverse long-run influence and causality from IM2 to the economy, this evidence cannot be inferred as indicating the existence of exogeneity in IM2 because money, as the medium of exchange, facilitates economic activities, making them easier and more efficient. Accordingly, Imam Ghazali (2013 M/1434 $\mathrm{H}$ ) argued that money is created to facilitate the exchange of goods. According to him, it is rational that hoarding money should be forbidden in Islam. Through hoarding, money is not available to facilitate the exchange of goods, so the economy will suffer difficulties in transactions. In other words, this causality is due to the money function as a medium of exchange.

In the second analysis of IM2 and prices, Indonesian and Malaysian banking produce different causality results. Indonesian IM2 has bidirectional causality with all prices, while in contrast, Malaysian IM2 only experiences bidirectional causality with stock prices, and unidirectional causality with property prices. This evidence indicates that Indonesian IM2 is less endogenous than the Malaysian in this second set of relations criteria.

To be specific, the bidirectional causality of Indonesian IM2 and price level (CPI) reveals the exogeneity of IM2 in two ways: (1) its causality to price means its contribution to inflation (Choudhury, 1997; Meera, 2002); and (2) the causality from CPI to IM2 shows that the exogenous factor of price intervention affects IM2, which will make any excess in IM2 to be absorbed by other prices (Meera, 2002). Meera's notion seems to be demonstrated by the existence of bidirectional causalities of IM2 and stock and property prices. In addition, Choudhury (1997) and Chapra (1996) argue that the speculative demand for money distorts IM2, so the causality from SP to IM2 supports this idea. Another type of exogenous money demand is related to property prices. Chapra (1996) states that Islamic money demand should eliminate luxury transactions. In the case of Malaysia, exogeneity only comes from stock and property prices.

The final criterion of endogenous money add evidence that Indonesian IM2 is less endogenous than the Malaysian. The causality $\mathrm{M}_{0}$ to Indonesian IM2 admits the exogenous monetary policy to IM2. Meera (2002) and Choudhury (1997) contend that this fiat money is the cause of an inflationary economy. However, the reverse causality from IM2 to $\mathrm{M}_{0}$ explains the endogeneity of money. Interestingly, Malysian IM2 has stronger causality (long- and short-run) than the Indonesian one (short-run). In spite of this, Indonesian IM2 experiences causality to IMI, which 
confirms the endogeneity of money, but not the reverse causality, which indicates the exogeneity of IM2. Interestingly, even though Malaysian IM2 does not have causality with IMI, neither does it have causality from IMI to IM2.

In the overall analysis, the endogeneity of Indonesian IM2 can be traced from the causality from the economy (IPI) to IM2, and the causality from IM2 to both monetary policies $\left(\mathrm{M}_{0}\right.$ and IMI). Nonetheless, exogenous factors come from three types of prices and $\mathrm{M}_{0}$. On the other hand, Malaysian IM2 experiences endogeneity from the economy (IPI) to IM2, and from IM2 to $\mathrm{M}_{0}$, with less distortion from prices. These results indicate that the greater maturity and bigger assets of the Islamic financial system lead to better money endogeneity. The Malaysian Islamic banking system started in 1983, while Indonesia opened its first Islamic bank nine years later, in 1992. Furthermore, Malaysian Islamic banks accounted for 38\% of total banking deposits in December 2019, while Indonesian Islamic banking assets were $5.99 \%$ of the total.

Finally, in spite of Chapra's (2008) criticism of Murabahah financing dominance, the endogeneity of money in the Islamic financial system based on fiat and fractional reserve requirement systems indicates a promising future. The evidence of causality from the economy to money supply proves the argument of Tohirin and Ghafar (2011), that the profit and loss sharing system is connected to the real economy. In addition, the evidence of Malaysian IM2 in minimising exogeneity through prices confirms the belief of Siddiqi (1982) and Ahmed (1983), who argue that a fractional reserve system will not harm the economy in the profit and loss sharing system. Finally, the causality from IM2 to monetary policies points out that the exogenous feature of fiat money can be eliminated.

\section{CONCLUSION}

\subsection{Conclusion}

It is concluded that the maturity and the greater asset share of the Islamic financial system supports the endogeneity of money. The experience of Malaysian Islamic M2 endogeneity compared to that of Indonesia one highlights the notion that the endogneity of money can be developed in the Islamic financial system based on fiat and fractional systems. In other words, a more mature profit and loss sharing financial system is able to connect the economy to money supply, minimising the exogenous aspects of the fractional reserve requirement, and eliminating the exogenous nature of fiat money.

\subsection{Recommendations}

The research recommends the need to develop Islamic financial systems. Therefore, regulators, scholars and practitioners related to Islamic financial institutions should play a role in making the Islamic financial system more mature and with a greater share of assets. In the case of other researchers, we suggest they continue the research on the endongeneity of money in theoretical terms, as well as empirically. We believe the discourse on endogenous money can be a bridge in the continuing debate on money in Islam, whether commodity or fiat money, and whether there should be fractional or $100 \%$ reserve requirement systems. 


\section{REFERENCES}

Ahmed, Z. (1983). Discussion on Al-Jarhi's paper. In Z. Ahmed, M. Iqbal, \& M. F. Khan (Eds.), Money and banking in Islam (pp. 91-101). Islamabad: Institute Policy Studies.

Al-Ghazali, A.-I. I. (2013 M/1434 H). Ihya' 'ulum al-din [Reviving the sciences of religion] (5 ed., Vol. IV). Lebanon: Dar Al-Kotob Al-ilmiyah.

Ascarya (2012). Transmission channel and effectiveness of dual monetary policy in Indonesia. Bulletin of Monetary Economics and Banking,14(3), 269-298.

Chapra, M. U. (1996). Monetary management in an Islamic economy. Islamic Economic Studies, 4(1), 1-36.

Chapra, M. U. (2008). Innovation and authenticity in Islamic finance. A keynote address presented at the inaugural session of the Eighth Harvard University Forum on Islamic Finance held on 19-20 April 2008 in the Harvard Law School.

Choudhury, M. A. (1997). Money in Islam: A study in Islamic political economy. London: Routledge.

Cyrille, S. M., \& Christophe, M. (2020). The endogenous money hypothesis: Empirical evidence from the CEMAC area (1990-2017). Journal of Post Keynesian Economics, October 2020, 1-27.https://doi.org/10.1080/01603477.2020.1835493.

Darrat, A. F. (1988). The Islamic interest-free banking system: Some empirical evidence. Applied Economics, 20(3), 417-425.

Darrat, A. F. (2000). Monetary stability and interest-free banking revisited. Applied Economics Letters, 7(12), 803-806.

Fikri, R. J. (2018). Monetary transmission mechanism under dual financial system in Indonesia: credit-financing channel. Journal of Islamic Monetary Economics and Finance, 4(2), 251-278.

Friedman, M. (2010). Quantity theory of money. In S. N. Durlauf, \& L. E. Blume (Eds.), Monetary economics (pp. 299-338). Basingstoke, UK: Palgrave Macmillan.

Haghighat, J. (2011). Endogenous and exogenous money: An empirical investigation from Iran. Journal of Accounting, Finance, and Economics, 1(1), 61-67.

Hassan, M. K., \& Aldayel, A. Q. (1998). Stability of money demand under interestfree versus interest-based banking system. Humanomics, 14(4), 166-185.

Ibrahim, M. H. (2020). Islamic banking and bank performance in Malaysia: An empirical analysis. Journal of Islamic Monetary Economics and Finance, 6(3), 87502.

IFDI (2019). ICD-REFINITIV Islamic Finance Development Report 2019. Retrieved March 2, 2021, from KNKS Web Site: https://knks.go.id/storage/ upload/1575958521-IFDI\%20REPORT\%202019\%20-\%20Reduced.pdf

Izhar, H., \& Asutay, M. (2007). The controllability and reliability of monetary policy in the dual banking system: evidence from Indonesia. International Islamic University Malaysia (IIUM) International Conference on Islamic Banking and Finance (IICiBF). Kuala Lumpur, Malaysia 23-25 April 2007.

Kaleem, A. (2000). Modeling monetary stability under dual banking system: The case of Malaysia. International Journal of Islamic Financial Services, 2(1), 21-42.

Keynes, J. M. (1936). The general theory of employment, interest, and money. London: Macmillan.

Kia, A. (1998). Interest-free and interest-bearing money demand: Policy invariance and stability. Working Paper 0214. Cairo: Economic Research Forum. 
Kia, A., \& Darrat, A. F. (2003). Modeling money demand under the profit-sharing banking scheme: Evidence on policy invariance and long-run stability. Paper presented at ERF's 10th Annual Conference Marrakech, Morocco, 16-18 December 2003.

Laidler, D. (1989). The bullionist controversy. In J. Eatwell, M. Milgate, \& P. Newman (Eds.), Money (pp. 60-71). London and Basingstoke, UK: Palgrave Macmillan.

Lavoie, M. (2005). Monetary base endogeneity and the new procedures of the asset-based Canadian and American monetary system. Journal of Post Keynesian Economics, 7(4), 689-709.

Meera, A. K. (2002). The Islamic gold dinar. Selangor: Pelanduk Publications (M) Sdn Bhd.

Mishkin, F. S. (2004). The economics of money, banking, and financial markets (7th ed.). New York, USA: Pearson Addison Wesley.

Moore, B. J. (1986). How credit drives the money supply: The significance of institutional developments. Journal of Economic Issues, 20(2), 443-452.

Moore, B. J. (1988). The endogenous money supply. Journal of Post Keynesian Economics, 10(3), 372-385.

Nell, K. S. (2000). The endogenous/exogenous nature of South Africa's money supply under direct and indirect monetary control measures. Journal of Post Keynesian Economics, 23(2), 313-329.

Newey, W. K., \& West, K. D. (1987). A simple, positive semi-definite, heteroskedasticity and autocorrelation consistent covariance matrix. Econometrica, 55(3), 703-708.

OJK [Otoritas Jasa Keuangan]. (2020). Snapshot Perbankan Syariah Indonesia 2020 [Snapshot of Indonesian Islamic Banking 2020]. Retrieved March 2, 2021, from https://www.ojk.go.id/id/kanal/syariah/berita-dan-kegiatan/publikasi/ Documents/Pages/Snapshot-Perbankan-Syariah-Indonesia-Maret-2020/ Snapshot\%20Perbankan\%20Syariah\%20Indonesia\%20Maret\%202020.pdf

Pollin, R. (1991). Two theories of money supply endogeneity: Some empirical evidence. Journal of Post Keynesian Economics,13(3), 366-396.

Shanmugam, B., Nair, M., \& Li, O. W. (2003, Summer). The endogenous money hypothesis: Empirical evidence from Malaysia (1985-2000). Journal of Post Keynesian Economics, 25(4), 599-611.

Siddiqi, M. N. (1982). Islamic approaches to money, banking, and monetary policy - A review. In M. Ariff (Ed.), Monetary and fiscal economics of Islam (pp. 25-42). Jeddah: International Centre for Research in Islamic Economics.

Skaggs, N. T. (1999). Changing views: Twentieth-century opinion on the banking school-currency school controversy. History of Political Economy, 31(2), 361-391.

Tohirin, A., \& Ismail, A. G. (2011). MMM in the finance-growth nexus. Investment Management and Financial Innovations, 8(3), 103-122.

Toutounchian, I. (2009). Islamic money and banking: Integrating money in capital theory. Singapore: Wiley.

Vera, A. P. (2001). The endogenous money hypothesis: Some evidence from Spain (1987-1998). Journal of Post Keynesian Economics, 23(3), 509-526.

Yousefi, M., Abizadeh, S., \& McCormick, K. (1997). Monetary stability and interestfree banking: The case of Iran. Applied Economics,29(7), 869-876. 